\title{
¿HABEAS REPRAESENTATIO? \\ Dilemas sobre la representación visual y narrativa de los sujetos de investigación en textos antropológicos
}

Sigifredo Leal Guerrero $^{1}$

Buena parte de la formación básica de los antropólogos pasa por que aprendamos a relacionarnos de maneras éticamente aceptables con los sujetos de nuestra investigación, y a analizar con pretensiones de objetividad los sentidos que elaboran sobre determinados aspectos de sus existencias. Pasa también por aprender a movernos con soltura entre el reconocimiento de dos axiomas que plantean cierta tensión cuando se los pone uno al lado del otro: aquél según el cual nuestro oficio impone aprendizajes continuos a partir de las realidades únicas de cada investigación, y el de que mediante el estudio del canon integrado por las obras de nuestros héroes culturales, el entrenamiento en cursos de técnicas de trabajo de campo y nuestra propia trayectoria, hemos incorporado cierta cosmovisión y habilidades que respaldan nuestro derecho a autodefinirnos como antropólogos y a ser reconocidos como tales. Así, con ese patrimonio de conocimientos, creencias y aspiraciones en la caja de herramientas, cuando nos enfrentamos a problemas prácticos planteados por la naturaleza de los objetos de nuestra reflexión nos lanzamos a buscar soluciones que nos parezcan satisfactorias o al menos aceptables, apelando a las vituallas que nos proporciona nuestra experiencia con la investigación de la cual se trate (por ejemplo el conocimiento de los "nativos" y los universos de relaciones sociales y sentidos que organizan sus vidas) y al corpus de saberes, principios y "tics" que hemos incorporado en investigaciones anteriores y mediante el estudio de literatura especializada. ${ }^{2}$ En este trabajo me referiré a dos experiencias de investigación empíricamente distintas pero analíticamente emparentadas, en las que se me ha planteado un mismo problema al que

\footnotetext{
${ }^{1}$ Institut für Ethnologie - Goethe Universität Frankfurt; Rosa-Luxemburg Stiftung, Alemanha.

${ }^{2}$ No hay que perder de vista que las soluciones que adoptamos nos parecen adecuadas porque son resultado de la articulación de nuestra experiencia en sentido amplio, las ideas académicas que encontramos de utilidad, y la realidad local del caso del que nos ocupamos. Pero es probable que esa apariencia se desvanezca si nuestras decisiones son impugnadas por los sujetos de nuestra reflexión o los miembros de la comunidad académica de pares, quienes viéndolas desde ángulos alternativos provistos por experiencias o paradigmas distintos de los nuestros, podrían encontrar fácilmente inconsistencias o equivocaciones que nuestra condición de artífices de tales soluciones nos dificulta ver a corto plazo. Esa consideración obliga a pensar en ellas como estrictamente provisionales, susceptibles de ser modificadas gracias a la crítica tanto de los protagonistas de nuestras investigaciones como de los colegas de las comunidades científicas, o de nosotros mismos si las miramos con "nuevos ojos" provistos por experiencias o lecturas posteriores.
} 
le he buscado solución mediante esa combinación de conocimiento del campo, patrimonio intelectual e inventiva: el de la nominación y la representación fotográfica y narrativa de los sujetos de mi reflexión en textos destinados a la circulación pública.

La primera de esas investigaciones le dio forma a mi tesis de maestría en Antropología Social en el IDES, en Argentina, y versó sobre los sentidos construidos por los hombres de Buenos Aires que se buscan y encuentran con propósitos eróticos a través de dos portales web y varios circuitos de la geografía urbana. ${ }^{3}$ La segunda constituye mi investigación doctoral todavía en curso, y en ella analizo la construcción de representaciones sobre la masacre del Palacio de Justicia de Colombia, un evento desatado por una toma de rehenes ocurrida en 1985 en el edificio principal de una de las ramas del poder público de ese país, que culminó con un número impreciso de desaparecidos que va de 12 a 18 y más de 100 muertos, varios de ellos ejecutados extrajudicialmente por las fuerzas del Estado que "recuperaron" el edificio. En ambas he desarrollado lo que George Marcus denomina "trabajo de campo multisituado", es decir que me he movido por diversos lugares físicos y electrónicos de acuerdo a "una lógica explícita, postulada, de asociación o conexión [...] que de hecho define el argumento de la etnografía" (citado por Robben, 2007: 331). Como explicaré cuando las aborde puntualmente, dicha lógica de asociación deriva en cada caso de las características objetivas del conjunto de relaciones sociales a las que los antropólogos nos referimos convencionalmente como "campo".

Pero el trabajo de campo multisituado y la relación problemática entre investigación y representación de los protagonistas no son lo único que vincula ambas investigaciones. Si bien lo distinto de sus referentes empíricos produce la impresión de que se trata de indagaciones inconexas, una consideración de los problemas que abordan pone en primer plano que ambas se inscriben en el mismo horizonte de preocupaciones. Ese horizonte está definido por la indagación sobre procesos conflictivos de construcción y legitimación de representaciones visuales y narrativas a propósito de aspectos de la realidad que se encuentran en el centro de abigarradas disputas, en las que se entrecruzan -entre otros-, la lucha y el activismo políticos, la construcción de identidades individuales y colectivas, y la disputa por la autoridad para decir verdades sobre la identidad masculina o la violencia política según el caso.

\footnotetext{
${ }^{3}$ Sus resultados principales fueron publicados en 2011 en la serie etnográfica de Antropofagia y el Centro de Antropología Social del IDES, en Buenos Aires, bajo el título La Pampa y el Chat: aphrodisia, imagen e identidad entre hombres de Buenos Aires que se buscan y encuentran mediante internet.
} 
En las dos siguientes secciones presentaré sucintamente ambas investigaciones, con el propósito de delinear el contexto en el que surgieron las cuestiones relativas a la nominación y representación de los protagonistas, que constituyen el objeto central de este artículo. En la tercera retomaré comparativamente dichas cuestiones y los modos en los que respondí a ellas, y en la cuarta propondré algunas conclusiones generales.

\section{La pampa y el chat}

Entre mayo de 2004 y diciembre de 2007 desarrollé periódicamente observación participante en las salas de chat y los perfiles personales de usuarios de Gay.com y Gaydar, los portales web de socialización homoerótica más usados entonces en Buenos Aires. Mis exploraciones consistieron principalmente en la lectura de perfiles, la participación en sesiones de chat y el sostenimiento de episodios de interacción mediada por internet o cara a cara con otros frecuentadores.

Decidí concederle un lugar predominante a esos portales en el trabajo de campo mientras recorría diversos circuitos geográficos y electrónicos de persecución del ejercicio de las aphrodisia, ${ }^{4}$ por la frecuencia con la que eran referidos en conversaciones sostenidas mediante internet y cara a cara en numerosos puntos de dichos circuitos. El trabajo de campo también supuso el desarrollo de entrevistas in situ cara a cara o mediante internet y, durante el período de cierre de las exploraciones, la aplicación de una prueba de lectura de fotografías publicadas por varios usuarios en perfiles personales. $^{5}$

He señalado que la focalización en los portales obedeció a la dinámica del trabajo de campo, pero también debo indicar que esos espacios electrónicos

\footnotetext{
${ }^{4}$ Estudiar la interacción homoerótica sostenida con la mediación de dispositivos electrónicos de comunicación implica reflexionar sobre la vida social-sexual cultivada en ausencia del contacto cuerpo-acuerpo. Por eso recurro a la noción de aphrodisia (en adelante sin cursiva) para denominar las actividades a través de las cuales los protagonistas de esas formas de interacción persiguen el intercambio de placeres eróticos. Retomo esa noción de la obra de Foucault, quien relevó el carácter indeterminado de las acciones asociadas a ella, englobadas por los griegos clásicos como "actos, gestos, [o] contactos que buscan cierta forma de placer [...] [en los cuales la] atracción ejercida por el placer y la fuerza del deseo que lleva a él constituyen, con el acto mismo de las aphrodisia, una unidad sólida" (2002 [1984]: 39). Ese desplazamiento de la mirada permite evitar aproximaciones excesivamente restrictivas por hacer énfasis en el contacto corporal, que hace tiempo dejó de ser imprescindible en numerosas sociedades urbanas. Una reflexión más amplia sobre las posibilidades y límites de la categoría en contextos como el referido se encuentra en mi libro de 2011.

${ }^{5} \mathrm{La}$ prueba consistió en la realización de entrevistas semiestructuradas con 5 de mis interlocutores permanentes mientras revisábamos 12 detalles de perfiles de Gaydar que contenían fotografías presentadas por los autores de los perfiles como personales ( 9 de esos detalles contienen al menos una imagen sexualmente explícita). Apuntaba a relevar los criterios según los cuales los participantes "leían" las fotografías, y a establecer si éstos hacían parte de su conciencia práctica o de la discursiva.
} 
constituyeron puntos de entrada tanto al campo como al desarrollo de mi socialización inicial en la Argentina, a donde me mudé desde Colombia en 2008 para adelantar mis estudios de maestría. Dicho de otro modo, el trabajo de campo constituyó una forma de conocer tanto el universo inmediato de relaciones sociales que investigaba como la sociedad argentina más amplia en cuyo marco éste adquiría sentido, y de la cual yo comenzaba a hacer parte. Como he anticipado, los portales no constituyeron un espacio aislado ni exclusivo en el trabajo de campo, tanto porque en ellos obtuve información parcial acerca de otros espacios que también frecuenté intensamente, como porque la concurrencia a parques, calles, baños, salas de cine pornográfico, clubes sexuales, discotecas y saunas, como el uso de una línea de chat telefónico, me permitieron dimensionar la importancia que tenían los portales entre los sujetos de mi reflexión, y reconstruir el contexto cultural amplio de la vida social que sostenían a través de ellos.

Una característica importante de esa vida social es que la mayoría de quienes la cultivan eligen nombres situacionales para ser usados en los portales, los cuales son compuestos con denominaciones que resulten atractivas para sus destinatarios ideales, y que al mismo tiempo refieran sintéticamente alguna característica considerada relevante para la interacción. Allí el nombre de pila resulta irrelevante y suele ser sustituido por nicks, para los cuales reservo acá la expresión "nombre" o "nombre situacional”. Dada esa particularidad del campo, casi siempre resultaba imposible establecer si los usuarios cuyo nombre situacional coincidía con un nombre de persona (como Lucasbien o Mati02), ${ }^{6}$ habían usado sus nombres de pila. Sin embargo tampoco intenté averiguarlo pues ello habría supuesto violentar la intimidad de esas personas, y esa reprochable indagación no habría aportado sustancialmente a la comprensión antropológica de los aspectos de la vida social que investigaba.

El intercambio entre nombres situacionales y nombre de pila por un lado obedece a que dar a conocer el segundo no es imprescindible para el establecimiento de episodios de interacción erótica, mientras el nick puede aportar datos fundamentales como la contextura física, las preferencias eróticas, la ubicación geográfica o la edad. Por otro lado expresa frecuentemente la distinción de las dimensiones pública y privada de la identidad social: se suele evitar el uso del nombre de pila en contextos de interacción homoerótica, pues las prácticas compartidas y presenciadas por los

\footnotetext{
${ }^{6}$ A fin de resguardar la privacidad de los sujetos de mi reflexión, en este y otros trabajos he cambiado todos los nicks y nombres de pila que conocí en el campo, sustituyéndolos por seudónimos en los que mantuve en la medida de lo posible el sentido de los originales.
} 
miembros de la comunidad erótica de pares pueden dar lugar a que fluya desde esos ámbitos a otros como el familiar o el laboral, lo que Erving Goffman (2003) denomina información destructiva respecto de la presentación de la persona ejecutada entre amigos, familiares o compañeros de trabajo.

Los nombres adoptados hacen referencia, entonces, principalmente a características autoatribuidas (duraverga, sexyman, machocoherente) y/o a los atributos que se espera que tengan los compañeros eróticos buscados (machoXmacho ["macho para macho"], neneXpapi ["nene para papi"]). Dicho de otro modo, remiten bien sea a lo que se tiene para ofrecer, a lo que se quiere obtener, o a ambas cosas. Acá entra en escena uno de los problemas de la nominación que anuncié al principio: ¿me libera la ausencia de nombres de pila de la obligación tan conocida por los antropólogos de resguardar la privacidad de los sujetos de nuestra reflexión empleando seudónimos, y puedo referir públicamente en textos sociocientíficos los nombres situacionales que conocí en el campo? Mi opinión, que el lector habrá encontrado anticipada en la nota al pie número 5, es que no. En ese mismo terreno de la representación de los "nativos" pero ya no en relación con la nominación sino con la ilustración fotográfica, se ubica un conjunto de otras cuestiones asociadas a la pregunta de cómo presentar las imágenes personales de esos mismos sujetos, habida cuenta de la imposibilidad de prescindir de ellas al hablar de una dimensión de la vida social en la que éstas ocupan un lugar central, y la necesidad de resguardar la privacidad de sus protagonistas. El problema se podría cerrar de golpe asumiendo que casi siempre se trata de imágenes exhibidas intencionalmente en perfiles personales públicos y por eso uno como investigador tiene derecho a presentarlas en otro contexto para bien de la ciencia, pero hoy me parece que esa sería una línea de conducta equivocada, si bien probablemente legal. Como en el caso anterior, voy a dejar ese asunto apenas planteado para retomarlo en la tercera parte, y continuar ahora con la descripción del contexto en el que esos problemas surgieron.

\section{"Todo pasa por la foto"}

Habitualmente los sujetos que me ocupan frecuentan salas de chat o perfiles asociados a su misma área geográfica, buscando otros con quienes resulte posible establecer contactos cara a cara. Esa elección generalmente coincide con la búsqueda de perfiles ilustrados con fotografías de sus autores, y expresa el interés de contactar sujetos respecto de los cuales -al menos teóricamente- las posibilidades de concretar 
encuentros sean elevadas tanto porque no estén lejos como porque sean visualmente atractivos. A la larga lo importante es moverse dentro de un radio en el cual se pueda "hacer algo" sin dilaciones con alguien que esté "bueno", un tópico en el que coinciden los frecuentadores y el eslogan de Gaydar: "lo que quieras, cuando quieras".

Pero además, tanto las fotografías personales publicadas o intercambiadas como las producidas en la rama pornográfica de la industria cultural propician en ese contexto la contemplación estética o, como diría Deborah Poole (2000: 27), son objetos que se encuentran vinculados al placer de mirar. Es decir que la búsqueda de oportunidades para ejercer las aphrodisia cuerpo a cuerpo no es el único motivo por el cual los usuarios exploran los perfiles personales de sus pares: esas exploraciones también están orientadas por la intención de ejercer la recreación erótica visual. Por eso además de navegar por perfiles de usuarios geográficamente próximos, los frecuentadores pueden contemplar los de otros residentes en regiones del mundo en las que ciertos fenotipos son más frecuentes que otros, o que merced a determinadas constituciones corporales o preferencias estéticas y eróticas convergen en salas de chat especializadas para osos, deportistas, maduros, etcétera. En esos sitios, entonces, el placer de mirar es a la vez estético y erótico, de modo que admirar fotografías personales o producidas en la industria cultural constituye en sí mismo un modo de ejercer las aphrodisia, que es perseguido en simultánea con los modos asociados al contacto corporal. Los portales constituyen, por eso, lugares antropológicos en los cuales la vida social se articula alrededor de la exploración erótica a escala individual o interpersonal, sobre la base de la producción, circulación y consumo de fotografías. Dicho en términos de uno de mis interlocutores permanentes, son lugares donde "todo pasa por la foto".

Sin embargo no todas las fotografías tienen el mismo valor con arreglo al propósito manifiesto de quienes utilizan cotidianamente los portales: el establecimiento de episodios de interacción homoerótica. En relación con esa dimensión, que es la más importante al menos al nivel de la conciencia discursiva de los frecuentadores, las fotografías personales ocupan el lugar central en tanto posibilitan la selección de potenciales compañeros eróticos, de modo que éstos incluyen permanentemente en sus perfiles o en los anuncios que emiten en las salas de chat expresiones del estilo "no pic [por picture] no chat" o "si no tenés foto ni lo intentés". Tal centralidad deriva del carácter de representaciones realistas que se les atribuye, y que depende de que comporten atributos objetivos (locación, apariencia del protagonista, definición, iluminación) a partir de los cuales sea posible diferenciarlas de las fotografías 
profesionales disponibles por doquier en internet, y tomarlas como garantía de primera instancia sobre la veracidad de la descripción que hace el otro de sí mismo en otras partes del perfil o en el chat.

Ese es el marco en el que la búsqueda de usuarios de los portales que estén dispuestos a respaldar fotográficamente su presentación personal, y el desarrollo de habilidades que permitan presentarse fotográficamente a uno mismo y leer las fotos de los demás, se concatenan para darle forma al sentido del juego que organiza las decisiones tomadas por los frecuentadores con arreglo a los fines que les son comunes. Como podrá revisarse in extenso en la obra sobre esa investigación publicada por Antropofagia (Leal, 2011), ese sentido del juego y el continuum de operaciones al que da lugar (producción, exhibición e intercambio de fotografías) pueden ser comprendidos como totalidad si se los analiza como parte de lo que Poole (Ibíd.: 16) denomina una economía visual de imágenes.

Por lo pronto lo que me interesa resaltar es que componer o seleccionar fotografías con el propósito de usarlas en la presentación personal en los portales posibilita, y al mismo tiempo exige, tomar decisiones orientadas a lo que Omar Calabrese (1989: 97) denomina "construir estrategias textuales", destinadas a respaldar la propia presentación personal y seducir a los otros. La construcción de esas estrategias se asienta no sólo en el control de la puesta en escena de las fotografías, sino frecuentemente también en la edición de ésta mediante programas de computadora que posibilitan recortar, distorsionar o borrar a voluntad rasgos físicos u otros elementos que no se desee exponer, como el rostro. Pero esas condiciones de producción también minan la verosimilitud que a efectos de la interacción se le atribuye a esas imágenes, y la consideración de esa contradicción posibilita comprender el hecho de que mientras el intercambio de fotografías personales ocupa un lugar central en ese contexto, permanentemente pesa sobre éstas la duda de si representan fielmente a quienes las exponen como propias.

Puesto en el contexto de la socialización en espacios en los que los nombres de pila suelen ser sustituidos por nombres situacionales, el ocultamiento del rostro al que me he referido líneas atrás aparece como un elemento más en la cadena de operaciones realizadas por los hombres que me ocupan con el fin de separar sus búsquedas del placer homoerótico de otras dimensiones de sus existencias como la vida laboral o familiar. Se trata de un desplazamiento coherente con la lógica de los modelos expresivos que ordenan la interacción en los portales, donde la identidad social 
individual de los actores es menos importante que sus atributos corporales o expectativas y habilidades sexuales. Así, a diferencia de lo analizado por otros autores sobre la preeminencia de la moralidad sobre la belleza en las masculinidades heterosexuales argentinas, 7 entre los sujetos de mi reflexión la belleza física es más importante que los atributos subjetivos, y esa jerarquía contribuye a determinar la centralidad que ocupan las fotografías de los otros en sus búsquedas.

Ahora quiero invitar al lector a poner en relación esa preeminencia de la belleza física con la preocupación por separar las búsquedas homoeróticas de otros ámbitos de la existencia, y con el hecho de que las posiciones en las que se presente un cuerpo fotografiado posibilitan inferir con algún grado de certeza el rol que prefiere asumir el sujeto representado durante los episodios de interacción homoerótica. Si me ha acompañado en el ejercicio ahora probablemente podrá dimensionar la densidad etnográfica del hecho de que en muchas de esas fotografías no sea exhibido el rostro, que como ha señalado Goffman (2001) es el asiento por antonomasia de la identidad social individual. Si se evita la exposición del rostro es, entonces, porque ésta abre la posibilidad de que espectadores indeseados asocien las dimensiones públicas de la identidad de los frecuentadores con sus intereses homoeróticos y sus roles sexuales favoritos. Y en este punto vuelve a entrar en escena la cuestión de la representación de los sujetos de estudio en textos sociocientíficos: ¿si frecuentemente los hombres de los que me ocupo publican fotografías en las cuales han borrado o alterado sus rostros (esos “asientos de la identidad social individual”), por qué no usar esas imágenes sin más, tal cual son publicadas por sus autores/protagonistas? Sobre esto también volveré en la tercera parte.

Como espero haber ilustrado en términos generales, el uso dado a las fotografías personales por los hombres que se buscan y encuentran mediante internet da cuenta de los modos en los que éstos aprovechan con fines eróticos el valor textual, e inevitablemente intertextual, de la representación naturalista. Y es precisamente esa característica de la dimensión de la realidad sobre la que me propuse indagar, lo que nos desplazó a la investigación y a mi de los estudios sobre sexualidades hacia otros terrenos, emparentando mi trabajo con los de autores con especificidades disciplinares tan diversas como Aby Warburg (2005 [1893]), Ernst Gombrich (2000), Omar Calabrese (1989) o Mary-Lousie Pratt (2010), quienes se han dedicado en diversos

\footnotetext{
${ }^{7}$ Cf. por ejemplo Archetti (2003) y Garriga y Moreira (2003).
} 
contextos a analizar e valor de uso textual de la representación naturalista en distintos momentos de la historia de las sociedades llamadas occidentales. Nótese que se trata en todos los casos de autores cuyas obras generalmente son profusamente ilustradas, como no puede ser de otro modo tratándose de trabajos en los que se analiza la producción, circulación y consumo de imágenes. Esa observación cuasieditorial conduce en el contexto de La Pampa y el Chat nuevamente a la pregunta por la representación: ¿cómo ilustrar los textos en los que se presentan los resultados de una investigación en la que ocupa un lugar central el análisis de fotografías personales, cuando éstas constituyen en sí mismas evidencias de prácticas que sus protagonistas frecuentemente intentan mantener en el terreno de lo privado?

\section{El epílogo del "Holocausto del Palacio de Justicia”}

El 6 de noviembre de 1985 un comando de la guerrilla del M-19 tomó las instalaciones del Palacio de Justicia de Colombia en Bogotá, sede de los más altos tribunales del país, exigiendo la publicación de documentos oficiales y la presencia del Presidente de la República para someterlo a un juicio público. A pesar del cautiverio de cerca de 300 rehenes y de que la radio transmitió las súplicas del presidente de la corte suprema de justicia para que el presidente de la república frenara la retoma del edificio por las fuerzas militares y negociara con los guerrilleros, el gobierno se negó a entablar conversaciones y el operativo continuó. Éste se extendió por 27 horas y supuso el uso de cargas de explosivos y tanques blindados con los que el ejército disparó contra el edificio y dentro de él, y durante su desarrollo se produjeron varios incendios que lo consumieron. Al final, tras dar el parte de misión cumplida, los comandantes de la retoma y sus subalternos desfilaron victoriosos con los tanques por el centro de Bogotá, y casi simultáneamente cuadrillas integradas por miembros de las fuerzas del Estado y empleados de una empresa de limpieza barrieron y lavaron las ruinas, amontonaron cadáveres y tiraron restos humanos carbonizados a la basura. Se calcula que la toma y retoma del Palacio dieron lugar a la muerte de 94 de las personas que se encontraban en su interior (CIDH: 1993), y que hubo 244 sobrevivientes (Carrigan, 2009: 347). Según

diversos testimonios orales y audiovisuales, varios sobrevivientes evacuados fueron asesinados por las fuerzas del Estado y posteriormente presentados como muertos en la 
operación, y de acuerdo a diversas estimaciones entre 11 y 18 sobrevivientes fueron sometidos a desaparición forzada. ${ }^{8}$

Si bien 27 años después de los acontecimientos continúa abierta la discusión sobre qué sucedió y quién fue el responsable de las muertes y desapariciones, la valoración de lo ocurrido como uno de los sucesos más dramáticos de la historia moderna de Colombia ha alcanzado la estabilidad de un topos en el repertorio de representaciones visuales y narrativas sobre el pasado reciente de la nación. En ese marco otro topos se ha ido consolidando gradualmente: para amplios sectores de la sociedad, en el Palacio de Justicia hubo un holocausto, es decir que según quién hable se dice que allí tuvo lugar un sacrificio colectivo, un asesinato en masa perpetrado por las fuerzas del Estado, o las dos cosas. Pero el uso de la denominación no es unánime, y hay quienes luchan por instalar interpretaciones distintas de lo que suelen llamar "la batalla", o "la toma y retoma del Palacio de Justicia", participando de ese modo en la configuración de un campo surcado por profundos desacuerdos y enconadas luchas no siempre desprovistas de violencia física, que se articulan al rededor de las discusiones sobre el significado del acontecimiento y las responsabilidades de sus protagonistas. Se trata en síntesis de disputas que expresan el hecho de que la construcción de versiones legítimas sobre lo sucedido y sus consecuencias es todavía un proceso en curso.

El eje de mi investigación es el relevamiento de las tramas de sentido desde las cuales esos diversos sectores en pugna interpretan lo sucedido en el Palacio de Justicia y lo representan visual y narrativamente mientras intentan instalar versiones hegemónicas sobre qué sucedió y quiénes son los responsables. ${ }^{9}$ Pero la preocupación por analizar cómo y desde dónde se construyen tales memorias no debe confundirse con la intención de desarrollar una aproximación como las que McAdam ([1996] 1999: 479) califica de ideal-valorativas por "centrarse en los discursos, escritos, comunicados y otras formas de pronunciamiento público de los activistas”. Tomando distancia en la medida de lo posible de ese tipo de trabajos, si bien considero tales formas de expresión también me

\footnotetext{
${ }^{8}$ El número de los desaparecidos y el motivo de su desaparición es, como muchos otros aspectos factuales del suceso, motivo de intensas controversias. Distintos cálculos sobre cuántos son los desparecidos pueden ser consultados en Maya y Petro (2006) y Comisión de la Verdad por los Hechos del Palacio de Justicia (2009).

9 Para ello me apoyo en el concepto de marco interpretativo, definido por Snow y Benford (citados y traducidos por Carozzi, 1997/1998: 34), como "un esquema de interpretación que simplifica y condensa el 'mundo allí fuera' mediante la selectiva puntuación y codificación de objetos, situaciones, eventos, experiencias y secuencias de acciones que se encuentran en el medio donde uno está presente. En palabras de Goffman, los marcos permiten a los individuos "ubicar, percibir, identificar y etiquetar eventos del espacio vital del individuo o del mundo más amplio’ [...].”
} 
ocupo de las acciones mediante las cuales esas memorias son frecuentemente construidas, actualizadas y hechas públicas por los agentes, por ejemplo en reuniones, actos conmemorativos, productos audiovisuales y montajes museográficos.

La intención de evitar el corsé del análisis discursivo por un lado se ha reflejado en mi determinación de concederle un lugar privilegiado al trabajo de campo etnográfico, y por otro ha dado lugar al desarrollo multisituado de ese trabajo. Tal carácter multisituado ha dependido tanto del hecho de que buena parte de la investigación ha progresado mientras he estado residiendo fuera de Colombia, como de que las luchas de las que me ocupo se dan en diversos lugares geográficos y electrónicos al mismo tiempo. En ese marco, la lógica de asociación que ha orientado mi deriva entre diversos espacios ha emergido de mi observación de que las memorias que analizo, que incluyen caracterizaciones tan distantes de lo ocurrido como concatenación de crímenes cometidos por agentes del Estado (uso excesivo de la fuerza militar, homicidio, secuestro, tortura, desaparición forzada, obstrucción de la justicia) o defensa de la democracia contra la conspiración judeo-marxista-jesuítica-masónica internacional, ${ }^{10}$ son construidas y actualizadas por agentes que ocupan distintos lugares geográficos y sociales, actúan en Colombia y otros países, y hacen públicas esas representaciones por distintos medios entre los cuales la internet es uno de los más importantes. $^{11}$

Por lo pronto mis indagaciones permiten dar cuenta de que los marcos interpretativos desde los cuales los actores que me ocupan construyen representaciones y luchan por legitimarlas están estrechamente vinculados con cuatro campos de la cultura que acá enumero sin jerarquizar: la tradición judeocristiana, la recepción local de los discursos eruditos globales asociados a los derechos humanos y la memoria de la Shoá, la ideología del antisemitismo anticomunista de estirpe nazi, y la Doctrina de Seguridad Nacional adoptada por buena parte de los gobiernos latinoamericanos durante la Guerra Fría. Dado que en este caso no me ocupo de un aspecto de la vida social sustentado en lo que los sujetos de mi reflexión hacen en privado como sucedía en la investigación sobre el ejercicio de las aphrodisia entre los hombres de Buenos Aires, sino que analizo luchas por la legitimación de memorias que por lo general tienen

\footnotetext{
${ }^{10} \mathrm{Al}$ respecto véase más ampliamente Leal y Gómez, 2012.

${ }^{11}$ Entre los espacios físicos en los que he desarrollado trabajo de campo se encuentran las ciudades de Bogotá, Medellín e Ibagué (Colombia), Buenos Aires (Argentina) y Malmö (Suecia). Entre los electrónicos, diversos portales y blogs mantenidos por activistas de los sectores enfrentados, la red social Facebook y los foros de lectores de las páginas web de medios noticiosos colombianos.
} 
carácter mayoritariamente público, las cuestiones relativas a la nominación y representación de los protagonistas de la investigación son completamente distintas de las que emergieron en ese otro trabajo. Digo "protagonistas de la investigación" y no "sujetos de mi reflexión", debido a que en este caso ha emergido un asunto que no planteó mayores problemas en la investigación a la que me referí en la sección anterior: el de la presentación de uno de esos protagonistas, el investigador, en los espacios en los que ha tenido lugar el trabajo de campo.

Antes de referir esas cuestiones y los datos que me han obligado a considerar los problemas relacionados con la nominación y la representación en este caso, debo hacer varias aclaraciones sobre el contexto general del trabajo en el que esos problemas han emergido. Primero tengo que señalar que a pesar de la relativa pacificación de Colombia y la campaña internacional del gobierno acerca de que allí existe una situación de postconflicto, en el país se sigue viviendo bajo un estado de guerra en el que el asesinato, la tortura y la desaparición forzada políticamente motivados son realidades cotidianas. Segundo, que el campo de disputa por la legitimación de memorias que es objeto de mi análisis se encuentra claramente polarizado entre quienes responsabilizan a los agentes del Estado por las muertes y desapariciones de sobrevivientes de la toma y retoma del Palacio de Justicia, y quienes los defienden y señalan a sus contradictores de aliados, agentes o "idiotas útiles" de "la subversión". Tercero, por las razones anteriores, las disputas que analizo se dan en una superficie aparentemente democrática bajo la cual corren las calumnias, amenazas y homicidios. Por ejemplo en 1998 Eduardo Umaña Mendoza, el abogado que representaba a los familiares de los desaparecidos en sus reclamos contra el Estado, fue asesinado por sicarios en su oficina del centro de Bogotá, y hasta el momento no se tiene información concreta sobre los autores del asesinato, ni sobre si éste obedeció a su participación en ese caso o en otros similares.

Junto al asesinato de Umaña se pueden enumerar varios casos de los que acá cito solamente tres. Uno de ellos son los periodos de exilio que ha vivido René Guarín, hermano de una desaparecida y reconocido activista de ese movimiento, debido a las amenazas de muerte que ha recibido en distintos momentos. Otro, las amenazas de muerte recibidas por Maria Estela Jara, la jueza encargada del proceso contra el Coronel Luis Alfonso Plazas Vega por la desaparición forzada de sobrevivientes del Palacio de Justicia, que la llevaron al exilio inmediatamente después de dictar sentencia condenatoria contra el coronel. Finalmente, el acoso laboral sufrido por la fiscal de ese 
caso y otros similares, Angela María Buitrago, que la llevó a renunciar a su cargo meses después de la condena del coronel Plazas, e incluyó una investigación de la Procuraduría General de la Nación en su contra por la inclusión en dicho proceso de una prueba presuntamente falsa cuya autenticidad fue posteriormente demostrada.

En ese marco, lo que me llevó a plantearme centralmente el problema de la nominación y la representación fue el descubrimiento de que en las disputas que analizo participa un frente sumamente dinámico de organizaciones y activistas de ultraderecha que luchan desde dentro y fuera del Estado y del país contra diversos fenómenos en los que ven el avance de los enemigos de la sociedad occidental y cristiana. Esos fenómenos incluyen, junto a las luchas por el derecho al aborto, al matrimonio entre personas del mismo sexo y un largo etcétera, la lucha de los familiares de los desaparecidos del Palacio de Justicia por conocer el paradero de esas personas y llevar a juicio a los agentes del Estado responsables de su desaparición, que en 27 años ha dado lugar a la condena de dos oficiales del ejército que dirigieron la operación de retoma. En el frente participan distintas organizaciones y el espectro es diverso, pero incluye actores como el expresidente Álvaro Uribe, su exministro del Interior Fernando Londoño, el ya mencionado coronel Alfonso Plazas Vega-condenado por la desaparición de sobrevivientes del Palacio de Justicia- y su esposa Tania Vega, ${ }^{12}$ el procurador general Alejandro Ordóñez - reconocido militante del fundamentalismo católico-, militantes de las organizaciones fascistas "Tercera Fuerza" y "Movimiento Vanguardia Nacional", y propagandistas sin filiación orgánica pública. Desde su perspectiva, quienes apoyamos la liberalización de las costumbres, la ampliación de los derechos democráticos de las minorías y el juzgamiento de crímenes de lesa humanidad cometidos por agentes del Estado, somos miembros de la legión de guerrilleros, comunistas, ateos, homosexuales, judíos-sionistas y otros empeñados en "destruir la sociedad mediante la combinación de todos los métodos de lucha".

En el caso del juzgamiento de agentes del Estado por delitos de lesa humanidad, dado que los reclamos y procesos adelantados en Colombia tienen equivalentes en otros países como la Argentina, el Perú o España, las actividades desarrolladas en el país por los miembros del frente se articulan con las que adelantan en el mismo sentido sus conmilitones de otros países. Han dado lugar, así mismo, a intentos de organización

\footnotetext{
${ }^{12}$ Yerno e hija del general Miguel Vega Uribe, señalado por numerosas víctimas y por el Consejo de Estado de 1985 de ser responsable de asesinatos, secuestros, torturas y desapariciones organizados desde la Brigada de Institutos Militares de Bogotá, que él comandaba.
} 
internacional por ahora expresados en la fundación de la ONG Unoamérica, desde donde unos y otros dan a conocer sus actividades locales y repudian los procesos en los que se juzga a militares por violaciones de derechos humanos. Según su análisis, tales juicios son meros remedos de justicia que ocultan la venganza de los sobrevivientes de la subversión derrotada, ahora infiltrados en el Estado y lanzados a la caza de los héroes que décadas atrás les bloquearon el camino hacia la toma del poder y la instauración de dictaduras marxistas. ${ }^{13}$

Por un lado el reconocimiento de ese panorama me ha permitido reconstruir mejor los marcos interpretativos con los que un sector de la sociedad colombiana elabora representaciones sobre lo acontecido en el Palacio de Justicia. Dichas representaciones integran elementos provistos principalmente por los marcos interpretativos propios del antisemitismo anticomunista nazi, el integrismo católico y la Doctrina de Seguridad Nacional impulsada desde los Estados Unidos durante la guerra fría. Pero por otro lado el hallazgo me llevó a dimensionar el impacto que la publicación de los resultados de mi investigación podría tener en la lucha de los familiares de los desaparecidos y quienes los apoyan directamente como abogados, amigos y miembros de ONG. También me hizo considerar la posibilidad de desencadenar sobre ellos, sobre mi o sobre mi entorno personal o familiar, acciones violentas perpetradas por los integrantes más radicales de dicho frente, como resultado de errores cometidos por mí durante el trabajo de campo, en la escritura de artículos o en mis intervenciones orales públicas.

Esa caracterización sobre mi como un sujeto potencialmente peligroso para los sujetos de mi reflexión (distintamente para cada sector), para mi entorno y para mi mismo no surgió, sin embargo, de la noche a la mañana. Emergió por un lado de considerar el uso que le podrían dar a los resultados de mi investigación los miembros de ese ya mencionado frente de ultraderecha si en la tesis, artículos o conferencias incluyera información que de alguna manera pudiera resultarles útil para lesionar la lucha de los familiares de los desaparecidos. Pero también derivó de la problematización de la relación que hay entre mi identidad social y mi ubicación en el campo, la cual me hizo ver que lo más probable es que por ser quien soy, los miembros de ese frente tiendan a ubicarme en la categoría de "enemigo".

\footnotetext{
${ }^{13}$ Cf. por ejemplo Villarruel, 2009 y Plazas Vega, 2011.
} 
Es decir que comprender la existencia de ese frente y lo polarizado del campo en el que se dan las disputas que analizo, dio lugar a que me percatara de que por los datos de mi biografía públicamente disponibles en internet y los que probablemente reposan en las agencias de inteligencia de Colombia, a las que con seguridad algunos de esos agentes tienen acceso, entro con holgura en las categorías no excluyentes de subversivo y miembro de la conspiración judeocomunista internacional. Por ejemplo, en la universidad participé activamente de movilizaciones y asambleas, como antropólogo ejerzo una profesión altamente estigmatizada como propia de guerrilleros, para la cual fui formado en la Argentina de los Kirchner y la reapertura de los juicios a los militares de la última dictadura, publiqué en ese país una investigación "sobre homosexuales", fui becario de Yad Vashem en Israel, estudio en Frankfurt ("sede de la famosa escuela judeocomunista homónima”, dirán muchos), y soy becario de una fundación llamada Rosa Luxemburg, entre otras cosas. En síntesis, se hizo evidente la escasa utilidad que en esos círculos tendría la presentación de mi persona que planeaba realizar durante el trabajo de campo, y que era coherente con cómo me veía a mi mismo entonces: como un investigador que pretendía escribir una tesis doctoral sobre qué decía cada quién sobre lo acontecido, y desde dónde lo decía, sin tomar partido por una versión u otra. ${ }^{14}$

Con esas consideraciones en mente consulté a otros con mayor conocimiento que yo de la realidad del conflicto colombiano, tanto porque han tenido en el país su residencia permanente durante los últimos años, como porque se ocupan de él como investigadores o activistas de los derechos humanos. Todos coincidieron con mi idea entonces vaga de reajustar el plan de investigación para no buscar contacto directo con los integrantes del mencionado frente. Como he ilustrado, mi biografía con seguridad daría lugar a que el estigma de enemigo me acompañara como la sombra al cuerpo en esos círculos, de modo que en un contexto tan polarizado como el colombiano mis acercamientos podrían ser interpretadas como actos de provocación y desatar respuestas violentas.

En ese marco, entonces, decidí centrar la observación participante en los círculos de quienes buscan saber qué sucedió con los desaparecidos y alcanzar el juzgamiento de los responsables de su desaparición, y aproximarme a los sentidos elaborados por los

\footnotetext{
${ }^{14}$ Un giro en la investigación sobrevino cuando me percaté de que mi pretendido objetivismo implicaba una buena dosis de relativismo que llevaba a nivelar como meras verdades emic las versiones articuladas por los familiares de los desaparecidos, y aquellas a través de las cuales los desaparecedores y sus partidarios en algunos casos niegan las desapariciones y en otros las justifican. Un análisis sobre ese giro ético que fue a la vez epistemológico puede ser consultado en Leal, 2013.
} 
militares acusados y sus partidarios prioritariamente a través de sus publicaciones escritas y audiovisuales. Adicionalmente, dadas las múltiples consecuencias que un incidente de gravedad nos puede acarrear a ellos y a mi, así como a las personas de mi entorno personal y profesional, a las instituciones locales que me acogen y a las alemanas a las que estoy vinculado, definí medidas preventivas de uso cotidiano y un plan de emergencia para responder a una amenaza inminente, los cuales no vale la pena detallar en este espacio.

Es por esa imposibilidad de desarrollar trabajo de campo clásico en todos los puntos del universo de relaciones en el que se desarrolla el fenómeno que me ocupa, que al reseñar líneas atrás la crítica de McAdam con respecto a las aproximaciones que él denomina "ideal-valorativas", he señalado que me he distanciado de ellas en la medida de lo posible. ${ }^{15}$ Por otro lado, comencé haciendo referencia a la relación entre trabajo de campo y riesgo de que el investigador sea objeto de violencia porque es en buena medida el asunto más fácil de resolver. Con esto no quiero decir que las soluciones efectivas se encuentren fácilmente, sino que si bien las medidas adoptadas pueden ser exitosas o fracasar y de esa diferencia quizá dependan la vida y la integridad del investigador, esos efectos indeseados del trabajo de campo pueden ser vistos indulgentemente por dramáticos que sean si se toma en cuenta que son riesgos calculados a pesar de los cuales uno decidió continuar con su trabajo. Sin embargo la situación cambia si se piensa esa misma articulación posible entre la investigación y sus consecuencias perjudiciales, pero en relación con el sector de los protagonistas con los que el antropólogo se encuentra comprometido. ${ }^{16}$

Como señalé anteriormente, en este caso el problema de la representación no tiene que ver con que los sujetos de mi reflexión -que en este caso conforman un grupo de apenas unas 50 personas-, busquen mantener en secreto las actividades que me

\footnotetext{
${ }^{15}$ Sin embargo el distanciamiento físico de quienes defienden a los militares procesados o condenados por desaparición forzada no ha sido completo. En las temporadas de campo de 2011 y 2012 desarrollé observación participante en un museo de Bogotá frecuentemente visitado por grupos de militares, en el que una unidad expositiva sobre lo sucedido en el Palacio de Justicia propicia comentarios en los que éstos generalmente expresan admiración por uno de los condenados. En mi ya citado trabajo de 2013 presento mis opiniones sobre esas experiencias y las reflexiones que reclaman acerca de su relación con el precepto del consentimiento informado.

${ }^{16}$ Empleo acá la expresión "comprometido" con en el sentido que le concede Falla cuando habla de la "antropología comprometida" (véase por ejemplo su entrevista de 1996 con Beatriz Manz). Es decir que me refiero al compromiso ético-político derivado de un determinado análisis de las relaciones de poder que le dan forma a los procesos sociales de los que el investigador se ocupa, y cuya implicación más inmediata es su toma de partido del lado de quienes según su análisis ejercen, por ejemplo, luchas justas, o dan cuenta de manera más objetiva que otros de hechos sobre los cuales existen interpretaciones contrapuestas en disputa.
} 
ocupan. Todo lo contrario, la mayoría de ellos ha sido profusamente representada fotográfica y audiovisual y narrativamente, tanto porque participan de actividades públicas ocasionalmente cubiertas por los medios de comunicación como conmemoraciones, mítines y audiencias, como porque dan entrevistas, participan en foros, seminarios, conferencias y actividades públicas similares. El problema no emerge, entonces, por la dificultad de equilibrar la necesidad de representar visualmente a los sujetos de la reflexión con el imperativo ético de no perjudicarlos, como sucedía en la otra investigación a la que me he referido.

Al contrario de lo que sucedía cuando desarrollaba trabajo de campo en los circuitos de persecución de las aphrodisia en Buenos Aires, entre los familiares de los desaparecidos y quienes los apoyan me muevo tranquilamente cámara en mano, tomo fotos de personas y documentos, filmo videos, y comparto con ellos selecciones de las fotografías que tomo de modo que éstas puedan ser incorporadas a sus propios archivos. Esa libertad es producto tanto de la relación de confianza que hemos construido, como del interés que tienen ellos de que su lucha sea visibilizada, para lo cual los registros fotográficos y audiovisuales hechos por terceros como periodistas, investigadores sociales o activistas, resultan fundamentales. Los problemas emergen cuando se trata de un tipo distinto de representación: la representación narrativa de la vida interna de ese grupo social.

¿Cómo representar públicamente aspectos tan interesantes antropológicamente como las tensiones políticas y morales que atraviesan ese grupo? Tómese en consideración que en un contexto académico signado por la abundancia de trabajos que ofrecen imágenes románticas de los movimientos sociales, los cuales aparecen representados como si fueran tan uniformes y apacibles que al leerlos es inevitable pensar al mismo tiempo en el estructural-funcionalismo y el romanticismo, el relevamiento de las contradicciones internas que surcan un grupo como aquél al que me vengo refiriendo sería útil para plantear desde el campo una discusión académica que resulta más que necesaria. Pero el relevamiento de esas contradicciones también dejaría expuestos aspectos de la vida social de ese grupo que podrían ser usados por sus enemigos, quienes gozan del poder que les concede su ubicación en la estructura de poder que ordena la sociedad colombiana y de ahí en adelante tendrían adicionalmente información de primera mano que les podría resultar de utilidad. ¿Qué hacer? ¿Aplicar seudónimos y describir con el mínimo grado de detalle necesario para referir las tensiones, sin exponer elementos que permitirían establecer claramente quién se pelea 
con quién? ¿No aludir abiertamente al referente empírico de la investigación, sino referirse de manera generalista a "un grupo de víctimas de crímenes de Estado"? De eso me ocuparé en la siguiente sección.

\section{La ubicuidad de la disyuntiva: representar a los sujetos de nuestra reflexión en textos destinados a "los otros"}

Como he ilustrado líneas atrás, en las investigaciones a las que acá hago referencia han sido las características del referente empírico las que han "impuesto" los problemas sobre los usos de las imágenes y la nominación de los "nativos" en textos destinados a circular en ámbitos distintos a los del universo de relaciones tejidas por ellos. Pero pongo entre comillas la referencia a la imposición para señalar que no se ha tratado del reconocimiento de problemas obvios puestos frente a mi paso por algún tipo de deus ex machina del trabajo de campo, sino de la emergencia de dudas provocada por mi encuentro con literatura y espacios de reflexión metodológica sobre las implicaciones éticas de la representación (fotográfica o narrativa) en la investigación antropológica.

Señalo ese aspecto anecdótico desde el principio para plantear varias cosas. Primero, que el lugar marginal que ocupa la reflexión ética explícita (aunque siempre se pueda argumentar que los antropólogos reflexionamos permanentemente de manera implícita) sobre las implicaciones éticas de nuestro trabajo, en cursos, congresos y seminarios, no contribuye a fortalecer nuestra reflexividad al respecto. Segundo, que como cualquiera de nosotros estaría dispuesto a aceptarlo, las cuestiones metodológicas no se presentan ante la mirada por sí mismas, sino que las construimos cuando problematizamos aspectos de nuestro trabajo desde un determinado ángulo ético y/o epistemológico, una labor imposible cuando carecemos de un repertorio de conocimientos pertinente. Tercero, que opino que deberíamos hacer esfuerzos por sacar de la periferia esas reflexiones y la literatura que las puede enriquecer, a fin de sofisticar la dimensión de nuestra reflexividad que nos posibilitaría abordar problemas como el de la representación visual o narrativa de manera menos ingenua, torpe o peligrosa.

Esta edición de Iluminuras, una revista en cuyos distintos números temáticos esa reflexión constituye una constante y por eso ha sido para mi un importante punto de referencia a lo largo del tiempo, ofrece la posibilidad de avanzar en ese sentido. Y al llegar a este momento del desarrollo de mi argumento tengo que hacer una aclaración 
histórica. Hay entre este artículo e Iluminuras una coincidencia que no tiene nada de accidental, pues mi encuentro con Cornelia Eckert y Ana Luiza Carvalho da Rocha a comienzos de 2010 en un curso sobre antropología visual en el IDES de Buenos Aires, introdujo un quiebre en mis preocupaciones sobre la relación entre la ética de la investigación social y la representación visual y narrativa de los sujetos de nuestras investigaciones. Debido a que en ese entonces ya había entregado el texto definitivo de mi tesis de maestría pero aún estaba en preparación su publicación, la comparación del manejo que le di al asunto en un caso y otro aporta argumentos a favor de la explicitación de la reflexión metodológica a la que me referí en el párrafo anterior.

En el texto de mi tesis de maestría que entregué para su evaluación por el jurado incluí imágenes originales tomadas de perfiles públicos de uno de los portales web en los que realicé trabajo de campo, y si bien cambié por seudónimos los nombres de pila de algunos sujetos a los que conocí suficientemente de cerca para tener acceso a esa información, no hice lo mismo con los nombres situacionales. Aunque bienintencionada, hoy me parece que la lógica con la que procedí entonces obedecía fundamentalmente a mi socialización en lo que Cornelia y Ana (2004: 7) han denominado "el consumo banal de la imagen técnica en la vida cotidiana": dado que las imágenes que incluí en la tesis habían sido expuestas por sus protagonistas en perfiles públicos de Gaydar, asumí que el que tomarlas de ese contexto para ilustrar un texto antropológico no representaba ninguna forma de vulneración de la privacidad de esas personas. Acostumbrado como estoy a la prácticamente desbordada circulación de imágenes personales en redes sociales de distinto tipo (amistosas, eróticas, académicas, de búsqueda de empleo), no vi un problema en extender el ámbito de circulación de imágenes que sus protagonistas no se preocupaban por mantener privadas. Algo parecido sucedió en relación con el uso de nombres situacionales: como éstos sustituían a los nombres de pila, en los que a mi parecer descansaban las asociaciones con la identidad individual, no parecía necesario sustituirlos por seudónimos.

Sin embargo las reflexiones intercambiadas con Ana, Cornelia y mis compañeros de ese curso en el IDES, y la bibliografía que estudiamos durante esos días, ${ }^{17}$ me hicieron revisar esas certezas. En relación con los nombres tuve que considerar el hecho de que si los de pila remitían a un parte de la identidad individual (la externa a los circuitos electrónicos de socialización homoerótica), los situacionales jugaban el mismo

\footnotetext{
${ }^{17}$ Por ejemplo las obras de McDougall 1998 y 2006, y Samaine 2005, entre otras.
} 
papel en un contexto igual de importante y personal: el de la vida social cultivada en los portales web. Tomando ese elemento en consideración se hizo evidente que la presentación de los nombres situacionales, si bien no exponía directamente la identidad de sus autores, tendía a dejar expuesta precisamente la dimensión de sus vidas privadas que constituía en parte el objeto de mi reflexión. Decidí entonces sustituir por seudónimos también esos nicks en el libro y los artículos a través de los cuales daría cuenta de los resultados de la investigación. El razonamiento siguió la misma línea en cuanto a las imágenes, pero pasó específicamente por la consideración de que si los protagonistas de las fotografías decidían hacerlas públicas en un contexto de la vida social, nada me autorizaba a separarlas de ese contexto sin su autorización para exhibirlas en otro. ${ }^{18}$

Entonces, durante la preparación de la publicación de esa investigación intenté establecer contacto con los autores de los perfiles cuyas fotografías quería usar como ilustraciones. La tarea casi fue un fracaso porque la mayoría de los perfiles que había incluido en mi archivo durante el trabajo de campo habían dejado de existir, de modo que solamente pude comunicarme con 3 autores de 12. Entre ellos, solamente uno respondió mi mensaje y me autorizó a usar su fotografía, de modo que interpreté el silencio de los otros dos como una negativa y excluí sus fotografías de mi repertorio de ilustraciones. Si bien compuse las demás ilustraciones apoyándome en las imágenes del grupo que ya había incluido en la tesis, las intervine intensivamente con el propósito de hacer irreconocibles a sus protagonistas oculté los nombres en el único perfil que presento en el libro (véase la imagen 1).

\footnotetext{
${ }^{18}$ En la citada obra de 2004 (p. 4) Eckert y Rocha presentan un panorama de la discusión teórica sobre los usos de la imagen en la investigación antropológica, y reflexionan sobre una situación similar a la que señalo. Se trata del caso de una persona que concedió su consentimiento para que las imágenes de sí fueran usadas en el contexto de una investigación, pero lo suspendió cuando las encontró usadas en una exposición organizada por el equipo académico de NAVISUAL en un museo, lo cual dio lugar a que el equipo las retirara inmediatamente.
} 


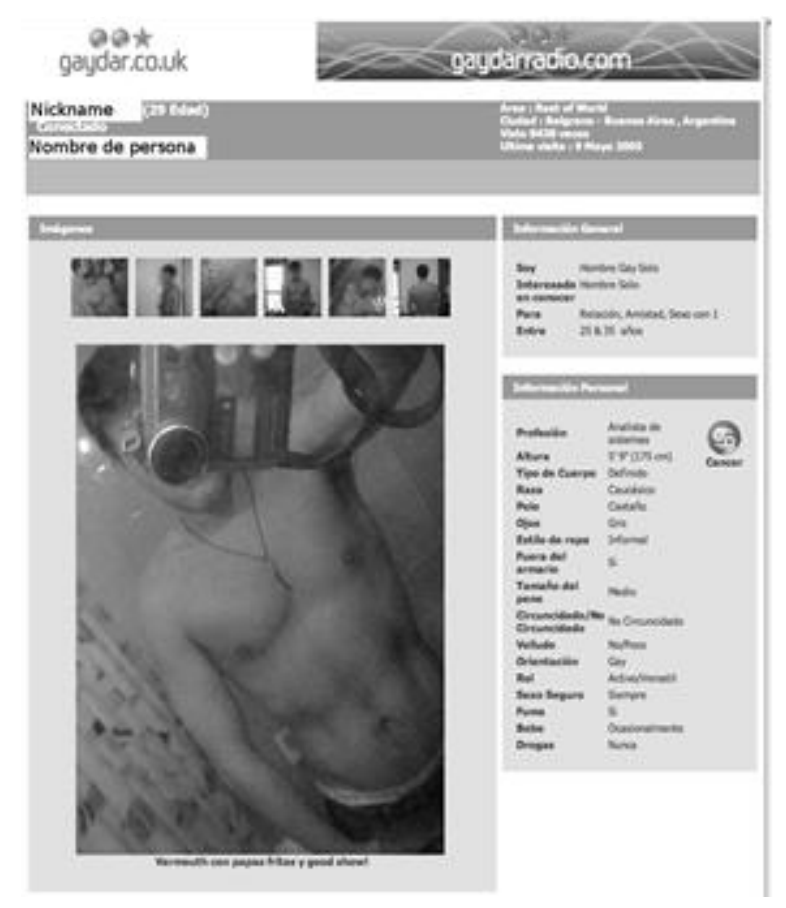

Imagen 1. Ilustración de La Pampa y el Chat (detalle, p. 59). El pie de foto original es el siguiente: "Perfil personal público en Gaydar. El nombre elegido por el usuario es similar a fachero-belgrano".

Las conclusiones de mi investigación, articuladas con las reflexiones que me provocaron las ya mencionadas discusiones y lecturas sirvieron para definir en detalle el guión de la edición de las fotografías. El sentido práctico de los protagonistas de mi investigación los habilita para interpretar con alto grado de precisión numerosos detalles presentes en las locaciones, y éstas también pueden permitir la identificación de las personas por parte de amigos y familiares conocedores de su espacio doméstico. Entonces, no solamente difuminé rostros y tatuajes cuando los había, agregué sombras de barbas y otros rasgos que se traslucían "por debajo" de las áreas difuminadas, sino que recorté digitalmente los cuerpos y los ubiqué sobre el fondo de locaciones completamente distintas de las originales, cuando la intervención de éstas agregando o eliminando objetos no era suficiente para transformarlas del todo (véase la imagen 2). 

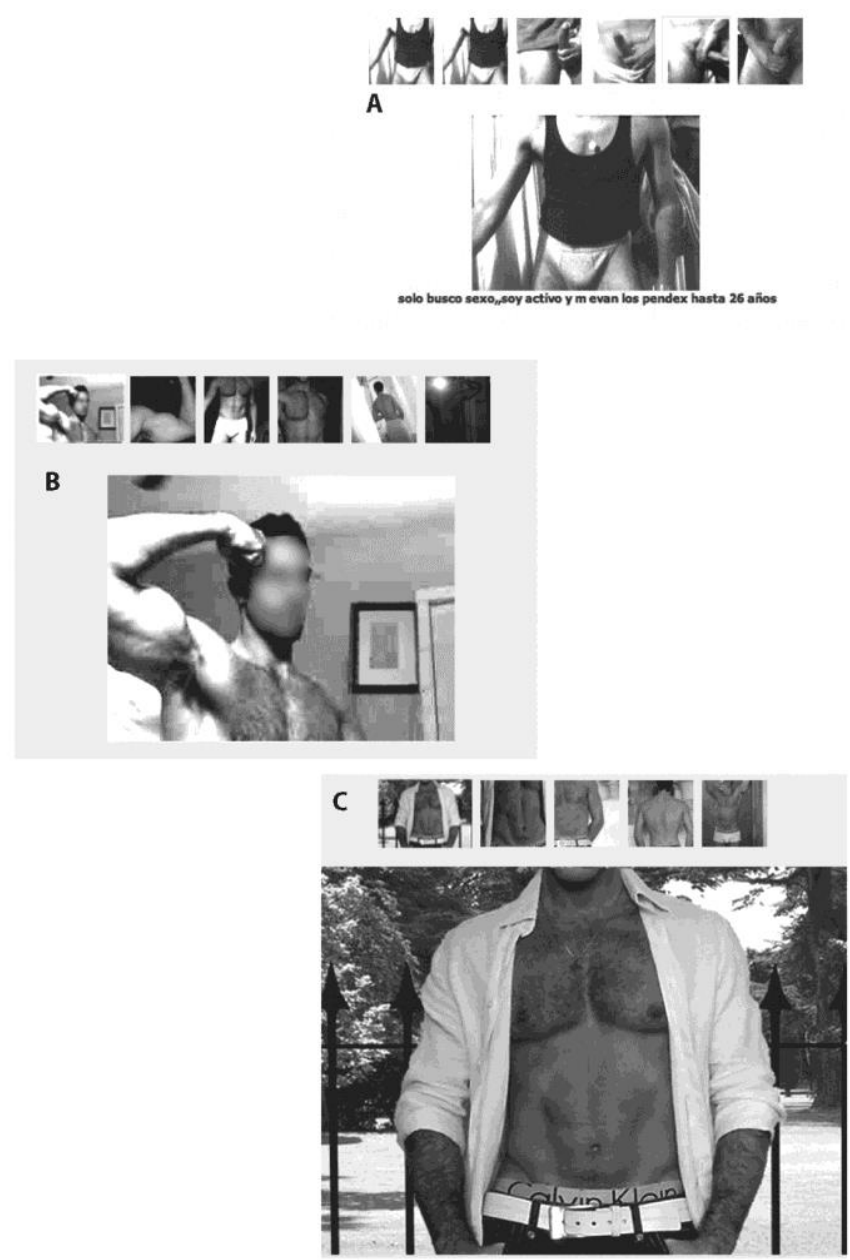

Lámina 1. Ejemplos de topoi fotográficos mediante los cuales se expresa frecuentemente la identidad de rol "activo" a través de perfiles personales públicos de Gaydar. Los autores eligieron nombres similares a sexonomas (a), mascs-solo (b, difuminación del rostro de autoría del etnógrafo) y aacorsario (C). Las imágenes se han introducido a la misma escala.

Imagen 2. Ilustraciones de La Pampa y el Chat compuestas con fotografías editadas intensivamente.

$$
* * *
$$

Dos problemas adicionales surgieron cuando tuve que definir la imagen de tapa del libro, y cuando me percaté de que mi archivo no contenía muestras de perfiles poco frecuentes pero relevantes en la investigación: aquellos en los que sus autores no manifestaba interés prioritario en establecer contactos eróticos. En el caso de la tapa decidí literalmente poner el cuerpo: usé una fotografía mía tomada ex profeso pero similar a las que había publicado en mis propios perfiles como usuario de esos portales, 
sobre la cual pegué la imagen de un pintada que alguna vez fotografié en una pared de Buenos Aires, cuyo contenido remite a la importancia del manejo de las impresiones entre los sujetos de mi reflexión (véase la imagen 3). Intentando salir del segundo impasse ubiqué perfiles activos de ese tipo y me comuniqué con sus autores contándoles sobre mi investigación y solicitando su autorización para usar sus perfiles como ilustraciones. Sin embargo éstos no me respondieron, de modo que con la ayuda de Jan, mi compañero, improvisé una solución "artesanal”: aunque él jamás había publicado un perfil en ese portal, me autorizó para ilustrar con sus fotografías uno compuesto por mi con las características que lo necesitaba. Por el encuadre y tamaño de las imágenes, éstas no parecían exponer su identidad individual (véase la imagen 4).

\section{La Pampa y el Chat Aphrodisia, imagen e identidad entre hombres de Buenos Aires que se buscan y encuentran mediante internet}
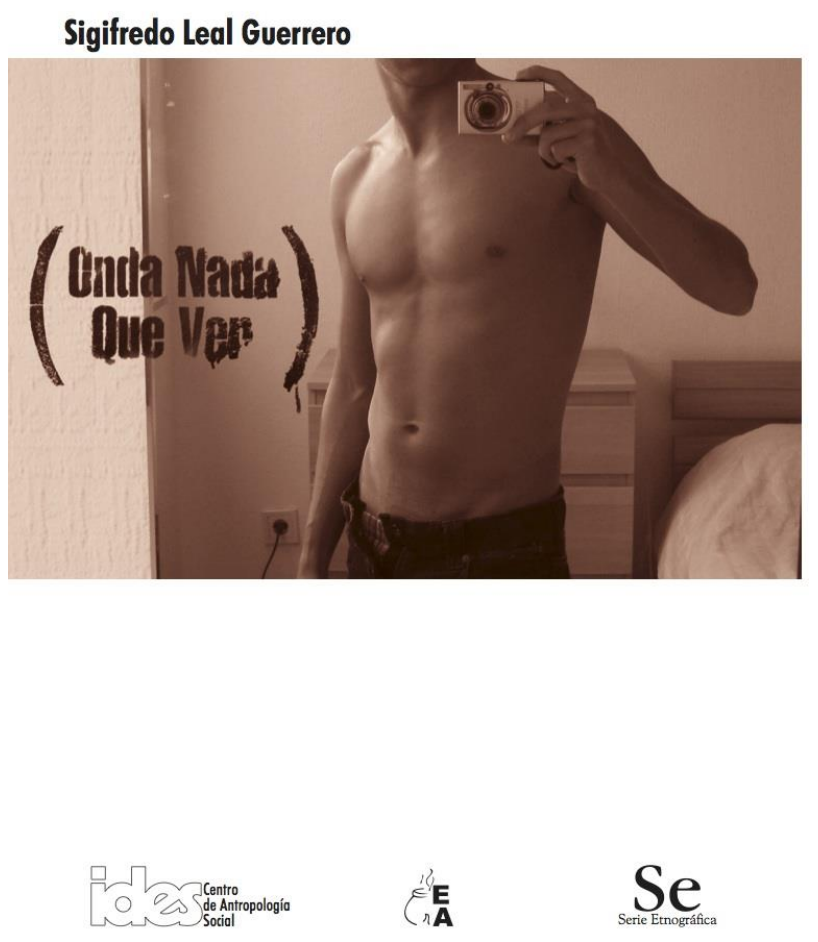

Imagen 3. Tapa del libro. 


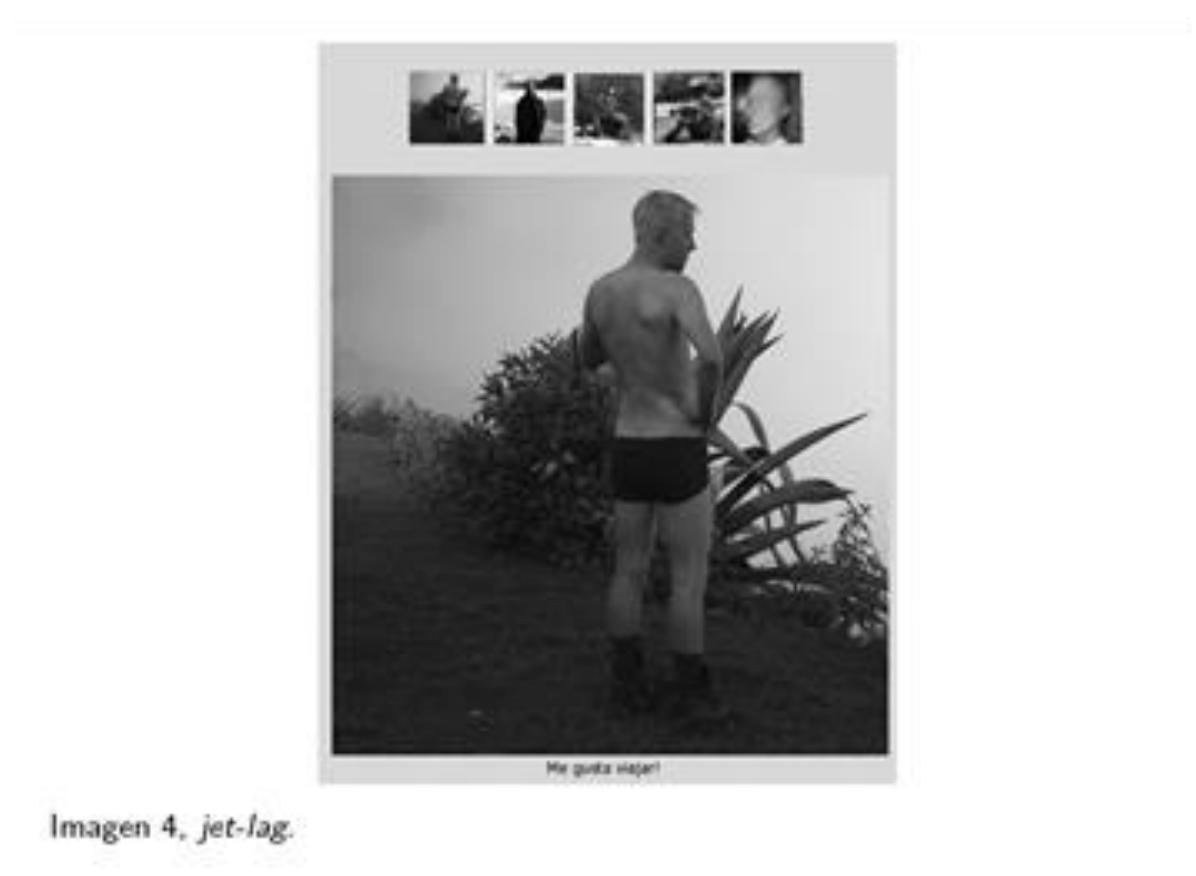

Imagen 4. Ilustración de La Pampa y el Chat (p. 90).

Los indicios más claros acerca de que la identidad individual no descansa solamente en el rostro y el nombre, y por eso había sido correcto editar intensivamente las imágenes tomadas de perfiles públicos para eliminar de ellas los marcadores de la identidad de sus protagonistas, emergieron cuando el libro comenzó a circular entre amigos y colegas. Muchos de ellos me reconocieron en la fotografía de la tapa a pesar de que en ésta solamente aparece mi torso, y el error que supuso no aclarar que el perfil ilustrado con las fotos de mi Jan era una "puesta en escena" dio lugar a preguntas francamente graciosas acerca de si nos habíamos conocido mientras yo desarrollaba trabajo de campo. De otra parte, las reacciones de los protagonistas de la investigación han sido escasas en cuanto a la obra en general, y si bien uno de ellos señaló haber reconocido a un antiguo compañero sexual por su cuerpo, aquellos que la han leído y comentado sus impresiones hacen poca referencia a las imágenes, y se centran en que la obra les resulta aburrida y difícil de leer porque es "demasiado científica".

Ahora bien, como ya he dicho, los problemas de la representación no pasan, en el caso de mi investigación sobre las luchas por la legitimación de memorias sobre la masacre del Palacio de Justicia de Colombia, por lo delicado del uso de la imagen, pues los protagonistas de esa luchas se encuentran permanentemente expuestos a las cámaras de los medios de comunicación, las de otros activistas e incluso las de los espectadores 
de sus actos públicos (véase la imagen 5). En este caso, como en el de las investigaciones de Frank Pieke (1995) sobre la lucha del Movimiento Chino del Pueblo de 1989 o Jeffrey Sluka (1995) sobre la organización clandestina del IRA en Belfast a inicios de la década de 1980, el asunto central es que la representación antropológica de aspectos de sus vidas que resultan del mayor interés científico puede facilitar acciones de terceros orientadas a perjudicar a las personas sobre cuyas vidas uno investiga. Al lado del problema de la nominación y las preguntas sobre si sirve de algo usar seudónimos, marcha entonces el problema de la representación narrativa.

Cerré la sección anterior haciendo referencia a la tensión que surge entre la posibilidad de poner en discusión desde el campo las representaciones románticas sobre los movimientos sociales que resultan comunes en la literatura antropológica, y la obligación de proteger la integridad de los sujetos de la investigación con los que uno se ha comprometido. A renglón seguido, como se recordará, plantee una serie de preguntas sobre la utilidad de no explicitar a qué organización se refiere el análisis que uno propone, o emplear seudónimos a la hora de referir las tensiones que atraviesan grupos como el que me ocupa. Ahora tengo que decir que por lo pronto mi impresión es que aquella es una oposición trágica en el sentido de que está planteada entre dos potencias que no tienen posibilidad de reconciliación. En la investigación sobre la memoria de la masacre del Palacio de Justicia, escribir públicamente sobre las tensiones que atraviesan el reducido grupo de personas que luchan por saber qué sucedió con los desaparecidos, y por el juzgamiento de los responsables de esas desapariciones, supone en cualquier caso hacer circular libremente información que podrían usar en su contra sus mucho más poderosos enemigos, quienes como he señalado conforman un frente cuyos miembros en algunos casos ejercen el poder desde instituciones del Estado. 


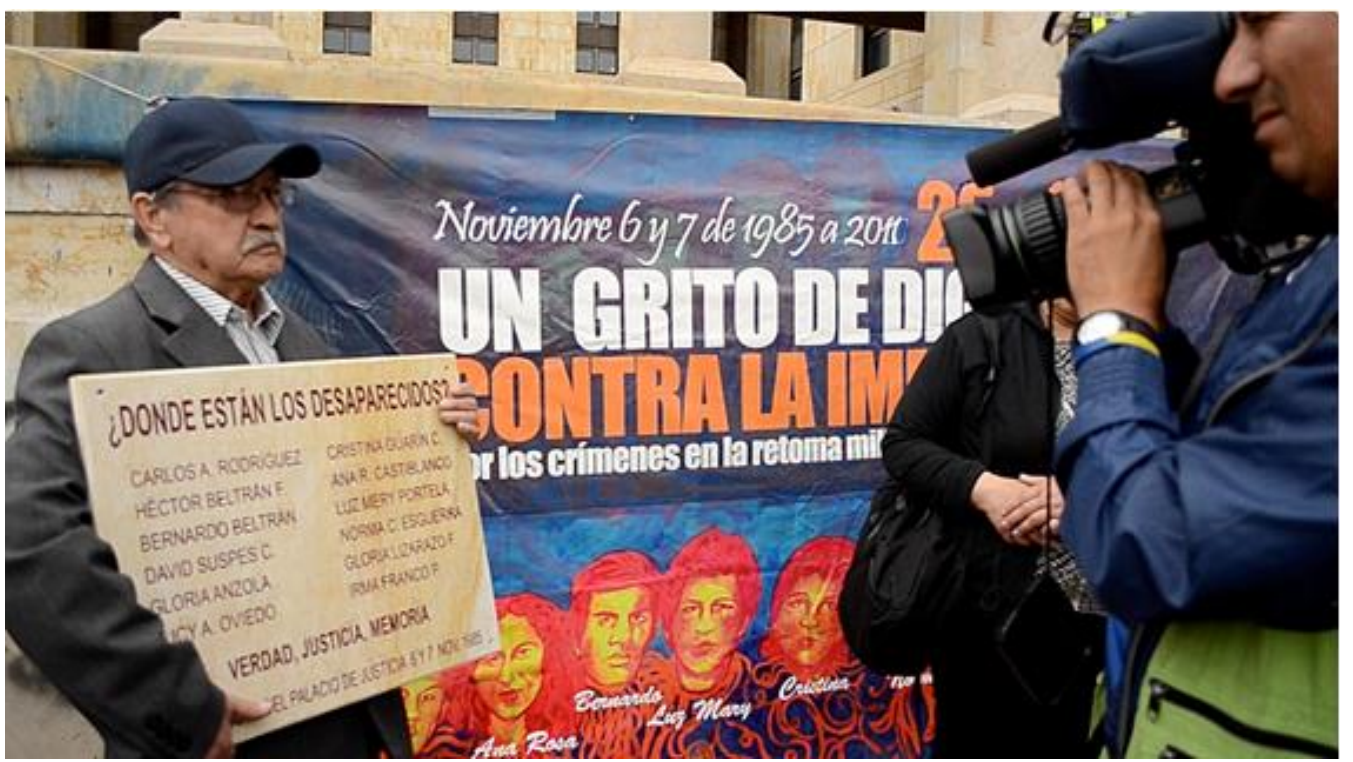

Imagen 5. Don Héctor Beltrán, padre de Héctor Jaime Beltrán, mesero de la cafetería del Palacio de Justicia desaparecido, al inicio de una entrevista para el noticiero televisivo RCN. Conmemoración del vigesimosexto aniversario de la toma y retoma. Bogotá, 6 de noviembre de 2011. Fotografía del autor.

Por un lado el carácter público de mi investigación sobre el problema anularía cualquier intento de ocultar el grupo del cual se trata bajo alusiones difusas y una denominación genérica, pues los integrantes de ese frente conocen la existencia de mi trabajo como mínimo desde octubre de 2012, cuando un airado defensor de uno de los militares condenados por las desapariciones asistió a una charla que ofrecí en Bogotá. Segundo, lo reducido del grupo, el carácter público de su lucha y el igualmente público reconocimiento de sus más dinámicos integrantes constituyen un sustrato en el que el empleo de seudónimos resulta inoperante. Dicha inoperancia queda en evidencia cuando se lee Vivir sin los otros (González, 2010), una novela de no-ficción que cuenta la historia de los familiares de dos desaparecidos, y en la cual es posible identificar las personas reales detrás de los personajes literarios a pesar de que éstos son presentados con nombres distintos, debido a que los lugares que ocupan en la toma y retoma del Palacio de Justicia y en las luchas posteriores son de conocimiento público.

En ese contexto, la combinación de calumnias, amenazas y agresiones físicas que componen la política desplegada hacia ellos por parte de los agentes del Estado señalados de ser responsables de los asesinatos y desapariciones, así com por sus partidarios, hace pensar que análisis antropológicos que aportaran información sobre 
contradicciones personales, familiares o políticas serían usados como insumo para perfeccionar campañas de desprestigio, trazar planes de desestabilización y complejizar formas de hostigamiento. Se trata, en síntesis, de una situación en la que si bien la representación visual no constituye un problema en sí misma, la representación narrativa pone sobre la mesa múltiples preguntas y obliga a pensar cuidadosamente en los efectos adversos que puede provocar la investigación sobre sus protagonistas. ${ }^{19}$ En este caso he preferido adoptar una posición que podría sintetizar con la expresión "habeas repraesentatio": puesto ante la disyuntiva, opto por respetar en toda la línea la potestad de los sujetos de mi reflexión con los que me siento comprometido, en lo que tiene que ver con la definición de los límites de su representación. Es importante aclarar, sin embargo, que si esa decisión por un lado significa abstenerme de reflexionar públicamente sobre ciertos aspectos de su vida social en tanto hacerlo podría ponerlos en peligro, por otro no supone el compromiso de circunscribir mi análisis, efectuado sobre otros aspectos, a la validación antropológica de las representaciones que esos actores elaboran de sí mismos. El habeas repraesentatio pasa entonces por la definición de los asuntos sobre los que no escribiré por razones de seguridad, pero no por la definición de qué escribiré sobre los demás temas.

Por eso durante el transcurso de esta investigación he decidido abstenerme de reflexionar públicamente sobre esas tensiones y desacuerdos, pero al mismo tiempo he explicitado sistemáticamente el hecho de que si no lo hago se debe a las razones éticas y políticas que ya he mencionado, y no a que el grupo de personas entre las que he desarrollado privilegiadamente trabajo de campo clásico se encuentre exento de contradicciones, o constituya una muestra de la inmanencia de la bondad humana. Adicionalmente, considerando la posibilidad de que en algún momento pierda el control sobre mis materiales si éstos fueran robados o espiados electrónicamente he decidido evitar tomar notas sobre algunos temas, nombres o roles, y enfocarme en aspectos

\footnotetext{
${ }^{19}$ Esa es una pregunta que no siempre se puede solucionar con respuestas unívocas. Por ejemplo si en este caso me siento compelido éticamente a no lesionar la lucha de los familiares de los desaparecidos, la confluencia entre el análisis de la evidencia empírica a la que he accedido en el trabajo de campo y mis nociones sobre la justicia provocan que no sienta la misma obligación con respecto a quienes niegan o justifican las desapariciones y defienden a los agentes del Estado condenados como responsables de ellas. En su caso, por ejemplo, me siento obligado a hacer públicos mis análisis de sus relaciones con el anticomunismo antisemita de estirpe nazi, o sobre las inconsistencias factuales de las memorias que intentan legitimar, a sabiendas de que dichos análisis contribuyen a minar la solidez de la presentación pública que realizan esos agentes como "meros ciudadanos independientes que simplemente se oponen a la arbitrariedad y la corrupción enquistadas en el aparato de justicia". Las reflexiones de Eckert y Rocha sobre el papel de la experiencia en la construcción de un conocimiento antropológico siempre situado (2000), y Bourgois sobre el trasfondo político del imperativo de neutralidad antropológica (2007) han sido fundamentales para formar mi opinión en este asunto.
} 
menos potencialmente lesivos de la vida social de ese grupo, como los modos en los que se articulan las trayectorias de vida y las memorias construidas, o las conexiones entre esas narrativas y la cultura colombiana tradicional. He intentado, a fin de cuentas, escuchar a Ricardo Falla (Manz, 1996) y no rendirme a los intereses intelectuales sin calcular el efecto de la investigación sobre las vidas de la gente con la que he llegado a comprometerme.

\section{Conclusiones}

A lo largo de este artículo he reflexionado, tomando como punto de partida las realidades de dos investigaciones empíricamente distintas pero emparentadas analíticamente, sobre los problemas que cada una de esas investigaciones me obligó a plantearme en lo referente a la representación visual y narrativa de los sujetos de investigación en textos antropológicos. También he dado cuenta de los modos en los que he enfrentado esos problemas, con soluciones que resultan coherentes con el marco provisto por el campo, mi experiencia y el patrimonio intelectual del que me encuentro provisto, pero que probablemente exhibirán inconsistencias y salidas en falso al ser analizadas desde otras perspectivas por mis interlocutores del campo o por colegas antropólogos. Así, si acá he dado cuenta de mi experiencia y las reflexiones que me provoca, es con el propósito de buscar el diálogo con otros cuya mirada distanciada podría resultar de utilidad para encontrar los puntos débiles de esas respuestas e introducirles ajustes que las hagan menos rudimentarias. Confío en que hacerlo en un número de Iluminuras donde otros colegas reflexionan sobre el mismo asunto, es una buena manera de propiciar las intervenciones parcialmente destructivas que siempre requieren los productos de nuestro trabajo para progresar y complejizarse.

\section{Referencias}

ARCHETTI, E. Masculinidades. Fútbol, tango y polo en la Argentina. Buenos Aires: Antropofagia, 2003.

BOURGOIS, P. "Confronting the Ethic of Ethnography: Lessons From Fieldwork in Central America”. En: ROBBEN, A. C. G. M. y SLUKA J. A. (eds.) Ethnographic Fieldwork: An Anthropological Reader. Malden: Blackwell, 2007.

CALABRESE, O. La era neobarroca. Madrid: Cátedra, 1989.

CAROZZI, M. J. "El concepto de marco interpretativo en el estudio de movimientos religiosos". En: Sociedad y Religión, 16 - 17. Buenos Aires: UBA, 1997. p. 33-52.

CARRIGAN, A. El Palacio de Justicia: una tragedia colombiana. Bogotá: Icono, 2009. 
CIDH - Comisión Interamericana de Derechos Humanos, 1993. Segundo informe sobre la situación de los derechos humanos en Colombia. Organización de Estados Americanos OEA (OAS), 1993.

COMISIÓN DE LA VERDAD SOBRE LOS HECHOS DEL PALACIO DE JUSTICIA, 2009. Informe final. Bogotá: Comisión de la Verdad sobre los hechos del Palacio de Justicia, 2009.

ECKERT, C. y Rocha, A. L. C. "A interioridade da experiência temporal do antropólogo como condição da produção etnográfica". En: Iluminuras, v.1, n.1. Porto Alegre: BIEV/ UFRGS, 2000.

FOUCAULT, M. Historia de la Sexualidad: II. El uso de los placeres. Buenos Aires: Siglo XXI Editores, 2002b. [1984].

GARRIGA, J. y MOREIRA, V. Dos experiencias etnográficas: similitudes y diferencias en el universo de las hinchadas de fútbol en Argentina. Florianópolis: UFCS, 2003.

GOFFMAN, E. La presentación de la persona en la vida cotidiana. Buenos Aires: Amorrortu, 2001.

GOFFMAN, E. Estigma: La identidad deteriorada. Buenos Aires: Amorrortu, 2003.

GOMBRICH, E. H. The uses of images: studies in the social function of art and visual communication. London: Phaidon, 2000.

GONZALEZ, F. Vivir sin los otros: los desaparecidos del Palacio de Justicia. Bogotá: Ediciones B, 2010.

LEAL GUERRERO, S. La Pampa y el Chat: Aphrodisia, imagen e identidad social entre hombres de Buenos Aires que se buscan y encuentran mediante internet. Buenos Aires: Antropofagia - Centro de Antropología Social del Instituto de Desarrollo Económico y Social, 2011.

LEAL GUERRERO, S. "Por la razón o por la fuerza: el antropólogo como testigo". En: Memorias del Encuentro Internacional Filosofía, Praxis y Sociedad. Bogotá: Uniminuto, 2013.

LEAL GUERRERO, S. y GÓMEZ ANGARITA, G.A. "El 'Holocausto del Palacio de Justicia': nombres, versiones y desacuerdos". En: Ensamblado en Colombia (en prensa). Bogotá: Universidad Nacional de Colombia, 2012.

MANZ, B. "Reflections on an 'Antropología Comprometida': Conversations with Ricardo Falla". En: NORDSTROM, C. Nordstrom y ROBBEN, C. G. M. A. (eds.). Fieldwork Under Fire: Contemporary Studies of Violence and Culture. Berkeley Londres: University of California Press, 1996.

McADAM, D. "Marcos interpretativos y tácticas utlizadas por los movimientos: dramaturgia estratégica en el Movimiento Americano Pro-Derechos Civiles". In: Movimientos Sociales: Perspectivas Comparadas. Oportunidades políticas, estructuras de movilización y marcos interpretativos culturales. Madrid: Istmo, 1999.

MacDOUGALL, D. "The subjective voice in ethnographic film". En: Transcultural Cinema. Princeton, New Jersey: Princeton University Press, 1998.

MacDOUGALL, D. "The visual anthropology". En: The corporeal image. Film, ethnography and the senses. Princeton, New Jersey: Princeton University Press, 2006.

MAYA, M. y PETRO, G. Prohibido olvidar: dos miradas sobre la toma del Palacio de Justicia. Bogota: Casa Editorial Pisando Callos, 2006.

PIEKE, F. N. "Withnessing the 1988 Chinese People's Movement". En: NORDSTROM, C. y ROBBEN, C. G. M. A. (eds.). Fieldwork Under Fire: Contemporary Studies of Violence and Culture. Berkeley - Londres: University of California Press, 1995.

PLAZAS VEGA, L. A. ¿Desaparecidos? El negocio del dolor. Buenos Aires: Dipón Gato Azul, 2011. 
POOLE, D. Visión, raza y modernidad: una economía visual del mundo andino de imágenes. Lima: Sur - Casa de Estudios del Socialismo y Consejería en Proyectos, 2000.

PRAT, M. L. Ojos imperiales. Literatura de viajes y transculturación. México: Fondo de Cultura Económica, 2010.

ROBBEN, A. C. G. M. "Multi-Sited Fieldwork". En: ROBBEN, A. C. G. M. y SLUKA, J. A. (eds.). Ethnographic Fieldwork: An Anthropological Reader. Malden: Blackwell, 2007.

ROCHA, A. L. C. y ECKERT, C. "Ética e imagem: un percurso". En: Iluminuras, v.5, n.11. Porto Alegre: BIEV/ UFRGS, 2004.

SAMAIN, E. "Por uma antropologia da comunicação: Gregory Bateson". En: SOUZA MARTINS, José de et al. O imaginário e o poético nas Ciências Sociais. São Paulo: EDUSC, 2005.

SLUKA, J.A. "Reflections on Managing Danger in Fieldwork: Dangerous Anthropology in Belfast". En: NORDSTROM, C. y ROBBEN, C. G. M. A. (eds). Fieldwork Under Fire: Contemporary Studies of Violence and Culture. Berkeley Londres: University of California Press, 1996.

VILLARRUEL, V. Los llaman “jóvenes idealistas”. Buenos Aires: Centro de estudios legales sobre el terrorismo y sus víctimas, 2009.

WARBURG, A. El renacimiento del paganismo: aportaciones a la historia cultural del Renacimiento europeo. Madrid: Alianza, 2005 [1932].

Recebido em: 29/11/2012

Aprovado em: 21/01/2013 